PRODUCTION

ENGINEERING

ARCHIVES
2015, Vol. 8, No.3, pp 22-27

ISSN 2353-5156 (print version)

ISSN2353-7779 (online version)

Articlehistory: Received: 06.09.2015

Accepted: 20.09.2015

Online: 30.09 .2015

\title{
Creating a pro-innovative strategy of enterprise development
}

\section{Oleksandr Oksanych ${ }^{1}$}

1Kielce University of Technology, al.1000-lecia PaństwaPolskiego 7, 25-314 Kielce, Poland, + 483424 440, oksanycz@tu.kielce.pl

\begin{abstract}
This chapter presents the theoretical, methodological and practical aspects of creating a pro-innovative strategy of development. It points out the need to choose between investing in the transfer of innovative products and the enterprise's own innovative activity. The author presents an algorithm of creating a pro-innovative development strategy, directions of developing cooperation networks in the field of innovation for the SME sector. The rules and criteria for assessing the effectiveness of the chosen strategy are proposed.
\end{abstract}

Key words - innovation, development strategy, company.

\section{Introduction}

An overview of scientific publications related to the problem of effective functioning of companies in conditions of globalization indicates that innovation is becoming an increasingly important factor in growth competitiveness (MARCINIAK S. 2010, PRAHALADC.K. 2010).

The effectiveness of the innovative activity depends as much on the state of the external environment, as well as the internal resources of the company. On the one hand, the external conditions affect the behavior of the company. The external environment must create the conditions in which innovative activity becomes a necessary and indispensable but "comfortable" (CLAYTON C.M. 2010, PANGSY-KANIA S. 2007).

On the other hand, the company must create those resources that are sources of innovative development.

These two aspects of pro-innovative development are closely linked with one another. Friendly innovative climate encouraging the mobilization of appropriate activity by the companies, whereas the practical activity in innovation scope generates demand for development innovation policy to adapt to business needs.

The quest for a strong competitive position requires the company to develop and implement appropriate strategies consisting of pro-innovative development. In this one of the key objectives of this strategy is to choose between their own innovations and their transfer.

\section{Methodology of research}

The research results are based on the available statistical data, scientific publications and survey measurements, carried out in the framework of the project Foresight "Priority technologies for sustainable development Świętokrzyskie Province" (Project No WKP_1 / 1.4.5 / 2/2006/20/23/601/2006 / U).

The basic methods used in the research process are statistical method, comparative method and method of an analysis of cases.

\section{Results and discussions}


As a result of innovative activity the company achieves external and internal effects (Fig. 1). These effects may have both a direct and indirect nature. Internal sources of direct benefits are changes in the

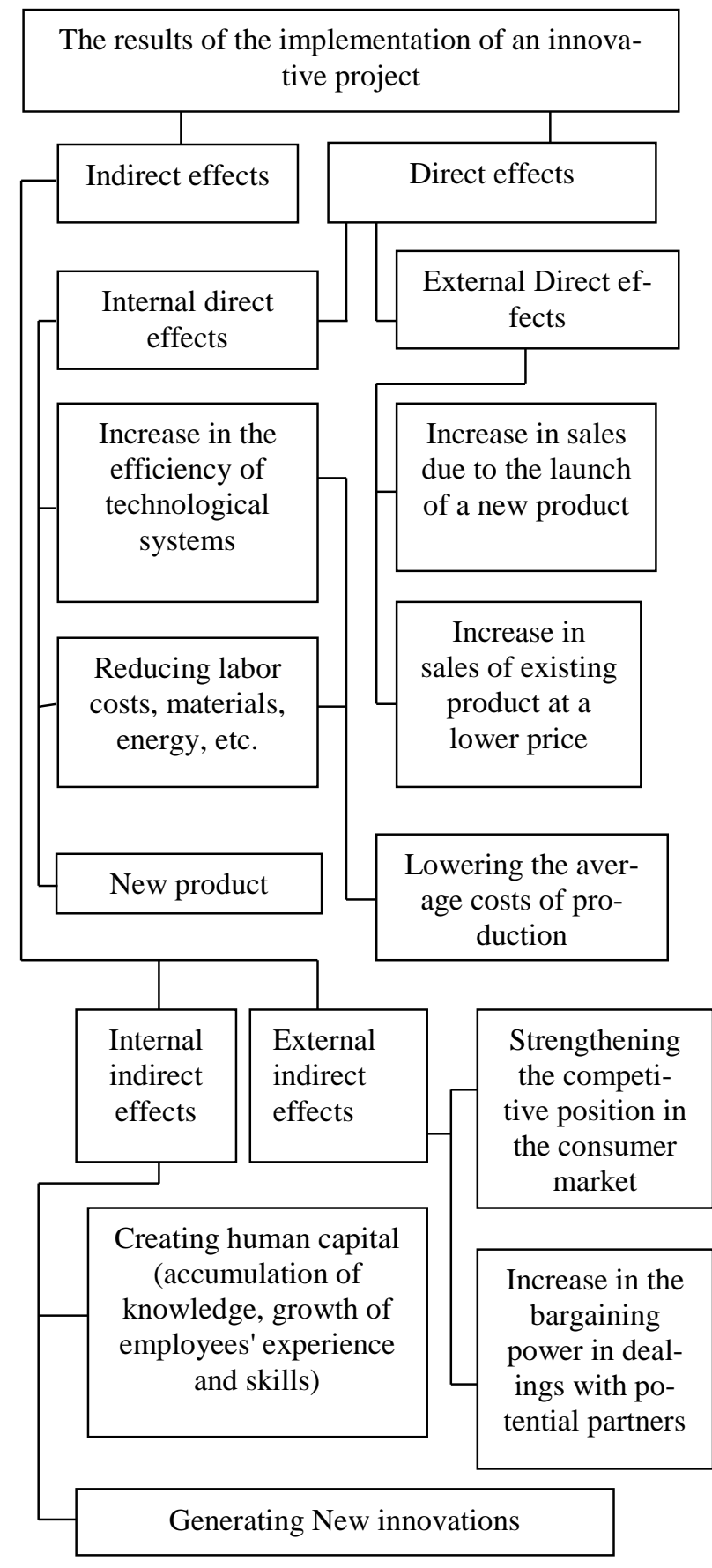

Fig. 1. The structure of the innovation effects.

Source: Own study production process systems, introduction of changes to the design of the company's own products, the use of new materials. The result is a reduction of the average total costs of production or a new product. The calculation of direct profits is quite simple because it is based on consideration of visible (expected) effects of the implementation of innovative products. External effects of innovative activity are the competitive advantages of the company on the market, which it gains through the implemented innovation. They are usually the higher revenues from sales of the current product at a lower price (because of lowering the average total costs of production and increased demand) or selling a new product which has no substitutes. In contrast, indirect profits are difficult to calculate. Therefore, it is necessary to use statistical methods, inter alia, methods of correlation and multiple regression.

As a result of undertaking innovative activity the company reaches a higher level of competitiveness, which is influenced by the nature of the activities carried out in this sphere.

Innovation is understood as the implementation of new solutions in the field of business activity (OECD 2005). These solutions are new for the company. They can be known on the market. Thus, the transfer of innovation from the external environment should be distinguished from innovation that is the result of the company's own R \& D activities ('own' innovation). Each of these forms of innovation has its advantages and disadvantages, of which the most important ones are shown in table 1.

'Own' innovation can ensure a long-term competitive advantage afforded by the use of unique innovative solutions, which are not available to competitors. The company can get even greater benefits from its 'own' innovation when it receives a patent or another certificate of copyright protection. At the same time, big risks and high costs of its own R \& D activities and implementation of their results must be taken into consideration.

On the other hand, the transfer of innovation does not need possessing the company's own R \& D base, a highly qualified personnel of R \& D units and it is associated with much smaller risks. Transfer costs are generally lower than creating the company's own innovative product. However, the transfer of innovation does not provide a long-term competitive advantage because every company has access to the same transferred innovative product. Usually the transfer of innovation is done not for providing a short-term competitive advantage, but as a tool for survival on the market, because competitors made such a transfer earlier. In the case of 
innovation transfer, higher marketing costs should be taken into account (OKSANYCH O. 2014).

Thus, 'own' innovations determine the competitiveness of the company. High costs, high risks and lack of adequate $\mathrm{R} \& \mathrm{D}$ resources mean that Polish companies often decide on the transfer of innovation, rather than generating their own innovative products (SZOPIKDEPCZYŃSKA K., DEPCZYŃSKI R. 2012).

According to PARP, the percentage of companies which conduct external $\mathrm{R} \& \mathrm{D}$ activities in the total number of operators in Poland in 2012 amounted to: in the small business sector $-2.1 \%$, average $-7.87 \%$, large $-23.5 \%$, the internal $\mathrm{R} \& \mathrm{D}$ activity - respectively $4.0 \%$, $29 \%$ and $29.3 \%$. although this is one of five lowest results among the EU countries (ZADURA-LICHOTA P. 2015).

An analysis of statistics on innovative activity of enterprises shows that expenditure on $\mathrm{R} \& \mathrm{D}$ has a tendency to grow. As the data in table 2 shows, those outlays in the enterprise sector in 2013 compared to 2010 increased by 2.2 times, and their share in expenditure on $\mathrm{R} \& \mathrm{D}$ in total in the same period increased from $24.4 \%$ to $37.3 \%$ (table 2).

Table 1. Advantages and disadvantages of innovation transfer and the company's own innovative activities

\begin{tabular}{|c|c|c|}
\hline & 'Own' innovation & $\begin{array}{l}\text { Transfer of in- } \\
\text { novation }\end{array}$ \\
\hline $\begin{array}{c}\text { Ad- } \\
\text { vantages }\end{array}$ & $\begin{array}{l}\text { - Allows the company to } \\
\text { achieve long-term com- } \\
\text { petitive advantage. } \\
\text { - Ability to sell the results } \\
\text { of their own R \& D activi- } \\
\text { ties. } \\
\text { - The possibility of obtain- } \\
\text { ing a multiplier effect. }\end{array}$ & $\begin{array}{l}\text { - Lower level of } \\
\text { risk. } \\
\text { - Relatively } \\
\text { moderate costs. }\end{array}$ \\
\hline $\begin{array}{c}\text { Disad- } \\
\text { vantages }\end{array}$ & $\begin{array}{l}\text { - High risk. } \\
\text { - High costs. } \\
\text { - The need to have the } \\
\text { company's own R\&D re- } \\
\text { sources and appropriate } \\
\text { staff. }\end{array}$ & $\begin{array}{l}\text { - It does not } \\
\text { provide long- } \\
\text { term competi- } \\
\text { tive advantage. }\end{array}$ \\
\hline
\end{tabular}

Source: Own.

Analyzing the dynamics of expenditures on innovation activities in industry, attention should be paid to an increase in funding the company's own innovations resulting from its own $\mathrm{R} \& \mathrm{D}$ activities, against a reduction in expenditures on the purchase of external knowledge (table 3).

Table 2. Expenditure on $R$ \& $D$ in Poland (million PLN)

\begin{tabular}{|l|l|l|} 
Year 2010 & Year 2012 & Year 2013 \\
\hline
\end{tabular}

\begin{tabular}{|l|c|c|c|}
\hline Total & 10416,2 & 14352,9 & 14423,8 \\
\hline $\begin{array}{l}\text { The govern- } \\
\text { mentsector }\end{array}$ & 6347,1 & 7367,6 & 6814,5 \\
\hline $\begin{array}{l}\text { The corpora- } \\
\text { tesector }\end{array}$ & 2543,1 & 4636,6 & 5384,3 \\
\hline
\end{tabular}

Source: GUS data.

Table 3. Expenditures on innovation activities in industry (million PLN)

\begin{tabular}{|l|c|c|c|c|}
\hline $\begin{array}{l}\text { Type of } \\
\text { expenditure }\end{array}$ & $\begin{array}{c}\text { Year } \\
2005\end{array}$ & $\begin{array}{c}\text { Year } \\
2010\end{array}$ & $\begin{array}{c}\text { Year } \\
2012\end{array}$ & $\begin{array}{c}\text { Year } \\
2013\end{array}$ \\
\hline Total & 14329,1 & 22379,0 & 20293,2 & 19520,2 \\
\hline On R \& D & 1367,1 & 3272,8 & 3529,7 & 3829,7 \\
\hline $\begin{array}{l}\text { On the pur- } \\
\text { chase of ex- } \\
\text { ternal } \\
\text { knowledge }\end{array}$ & 625,1 & 1362,4 & 1026,9 & 542,8 \\
\hline $\begin{array}{l}\text { On invest- } \\
\text { ment in ma- } \\
\text { chinery and } \\
\text { technical } \\
\text { equipment }\end{array}$ & 8392,7 & 11711,6 & 11862,3 & 10489,0 \\
\hline \multicolumn{2}{|l|}{ Source: GUS data } & & & \\
\hline
\end{tabular}

In 2005 the share in expenditure on R \& D in the overall expenditures on innovative activity in the industry amounted to $9.54 \%$, whereas in 2013 it already was $19.6 \%$. During this period, expenditure on R \& D increased by 2.8 times.

The dynamics, however, are still insufficient compared to other countries. According to the Global Competitiveness Report, investments of Polish companies in $\mathrm{R} \& \mathrm{D}$ were assessed in 2013 as 2.8 compared to 3.8 in 2006 (on a scale of 1 to 7). This means that regardless of the positive dynamics of expenditures on $R \& D$, the effort of enterprises in this area is insufficient against global trends (table4).

Presented in the table X.4 data indicates that positive trends compared to 2012 are shown only by the indicator of 'capacity for innovation' - a change from 3.3 in 2012 to 3.8 in 2013-2014 (on a scale of 1 to 7). And although companies more actively invest in their own $\mathrm{R}$ $\& \mathrm{D}$, in comparison with technologically developed countries, this growth rate is not sufficient.

It would be a mistake to analyze the development of enterprises' own innovation without taking into account the conditions of innovative activity in the country. And those do not show positive trends in development. As it can be seen from the presented evaluations of specific indicators in the years 2005-2013 in Table X.4, the majority of them show a clear downward trend, which results, at the last count, in a decrease in the level of innovation in the economy as a whole. The solution to the 
problem needs not only willingness and respective intentions to invest in the company's own R \& D activity. The appropriate national innovation policy and consistent action for its implementation are necessary. Today, according to scientists and representatives of business, such a policy does not exist in Poland. (Kluzek M. 2013).

Table 4 Innovativeness of Polish enterprises and the conditions for innovative activity

\begin{tabular}{|l|c|c|c|}
\hline $\begin{array}{l}\text { Indicators and factors of in- } \\
\text { novation }\end{array}$ & $\begin{array}{c}\text { Year } \\
2006\end{array}$ & $\begin{array}{c}\text { Year } \\
2012\end{array}$ & $\begin{array}{c}\text { Average } \\
2013- \\
2014\end{array}$ \\
\hline $\begin{array}{l}\text { The quality of research in- } \\
\text { stitutions }\end{array}$ & 3,8 & 4,1 & 3,9 \\
\hline $\begin{array}{l}\text { Investments of companies } \\
\text { in R \& D }\end{array}$ & 3,8 & 2,9 & 2,8 \\
\hline $\begin{array}{l}\text { Collaboration of industry } \\
\text { with universities }\end{array}$ & 3,6 & 3,6 & 3,5 \\
\hline $\begin{array}{l}\text { Orders by the government } \\
\text { for technologically ad- } \\
\text { vanced products }\end{array}$ & 3,6 & 3,2 & 3,2 \\
\hline $\begin{array}{l}\text { Availability of scientists } \\
\text { and engineers }\end{array}$ & 4,2 & 4,2 & 4,2 \\
\hline The ability to innovate & 4,1 & 3,3 & 3,8 \\
\hline Innovativeness in total & 3,5 & 3,3 & 3.3 \\
\hline
\end{tabular}

Source: Own study based on (SCHWAB K. 2014).

Pro-innovative development of the company envisages developing an appropriate strategy. Unfortunately, strategic planning is realized mainly by large companies. 'More than a half of small and medium-sized companies in Poland does not have a development strategy - according to a report by the Polish Agency for Enterprise Development on strategic planning in companies. Only 31 percent of respondents declare to have a vision for their business, of which only 10 percent write it in the form of a document.' (WNP.PL 2014).

Compared with the other types of functional strategies, preparing a pro-innovative strategy of development must take into account the greater risks. Managers should pay attention primarily to risk factors in the case of an innovation-oriented development strategy, in contrast to existing techniques of creating a development strategy. Therefore, the development of such a strategy must anticipate the following basic steps (Fig. 2):

1.Establishment of objectives.

2. Identification of possible ways of achieving the objectives based on analysis of operating conditions.

3. Evaluation of risks.

4. Evaluation of effectiveness.

5. Selection of the optimal choice in the coordinates 'profit-risk'.
The choice of the optimal strategy must take into account not only the direct effects of its implementation. Whenever possible, decision-makers should also assess the indirect effects from the perspective of a strategic planning horizon. This primarily relates to the developmental prospects of the company's intellectual capital.

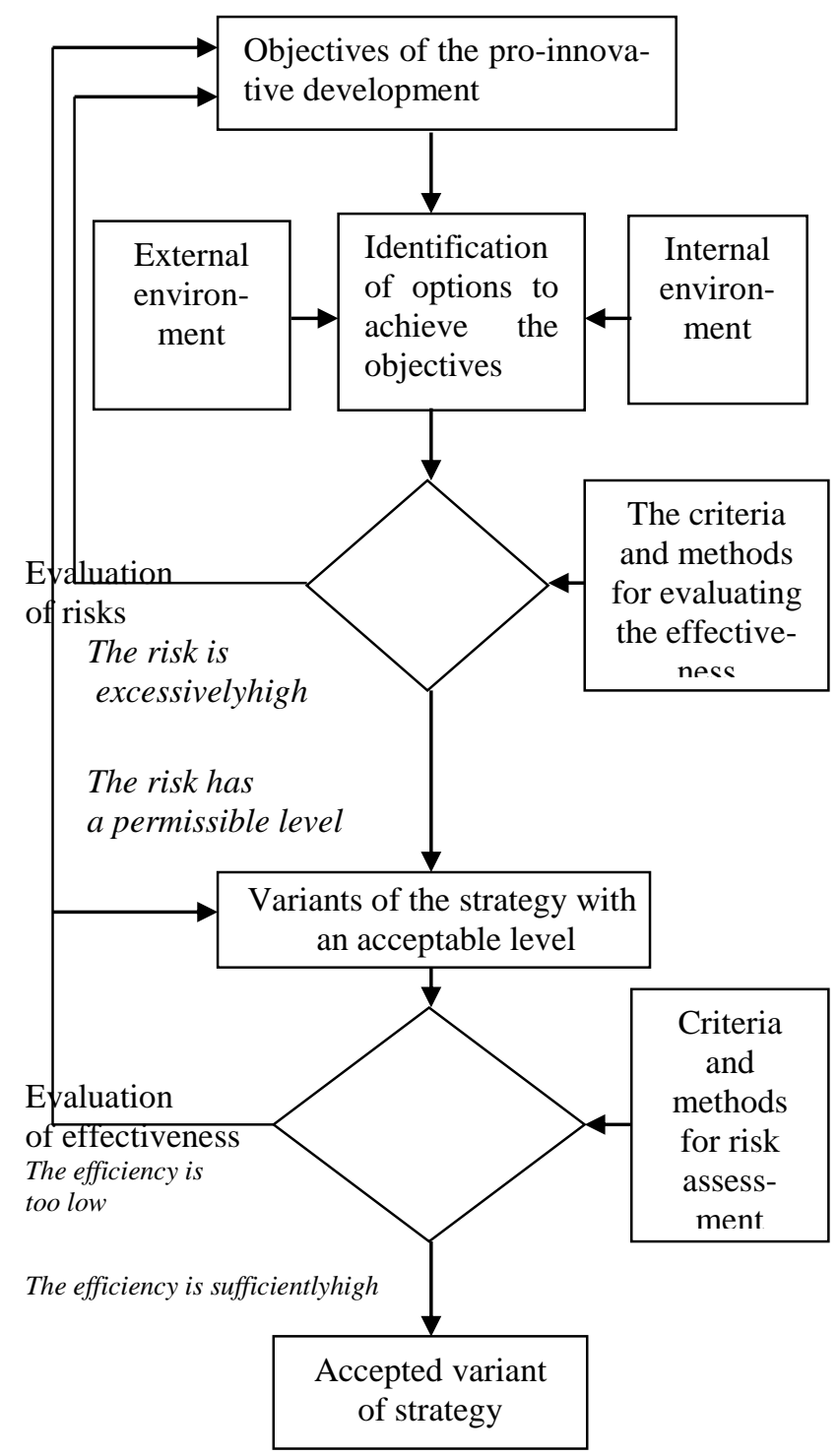

Fig. 2. The scheme of selecting the optimal strategy for pro-innovative development with taking into account the risk.

Source: own study

One of the key problems of pro-innovation development in Poland is low involvement of the SME sector in innovative activity. Small businesses have limited possibilities of financing their own R \& D and do not have adequate facilities in the form of $R \& D$ units. However, the potential of the SME sector is effectively used in 
technologically advanced countries. The solution to the problem needs an adequate support from the state, local authorities, large companies and the specialization and cooperation of the SME sector in the framework within the created cooperation networks. Even a good innovation needs support.The advantages of cooperation in the network are: the ability to raise additional funds and resources; implementation of joint projects which cannot be accomplished separately due to a variety of reasons; the possibility of introducing innovations to the market at a lower cost; access to information and knowledge enabling some support for the creation of human capital; the possibility of outsourcing with partners; participation in risks.

Participation of a large company, which occupies the position of a leader or challenger in the market is necessaryto create a network for innovation. There may be a few such companies. For large companies the creation of networks has its advantages:

- reduction of costs ( for small firms the delegation of tasks by a large corporation is itself a big incentive and opportunity);

- the possibility of diversifying activities in case of asuccessful innovation, generated by the involvement of small businesses;

- the possibility of choosing the best ones among the SME sector.

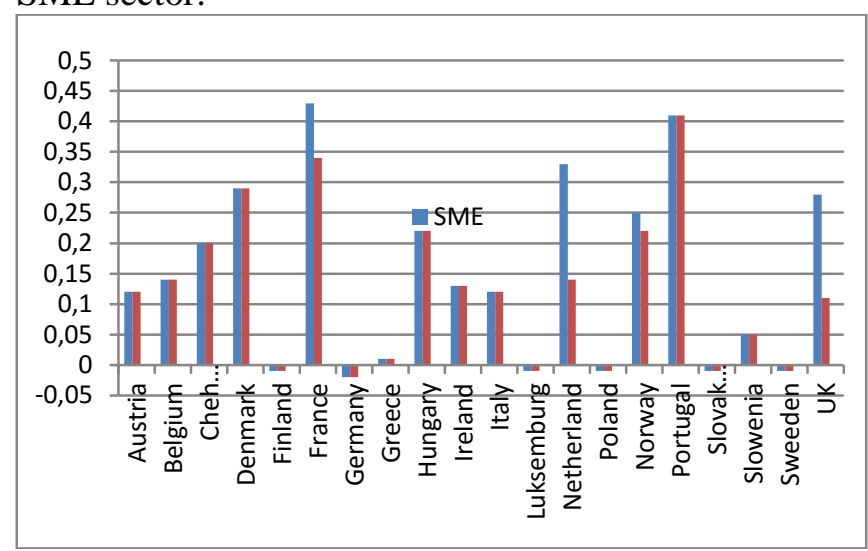

Fig. 3. The index of fiscal support for investment activities
in Europe.

Source: Own study based on ( STEWARD L and others 2012).

Another course of action is to develop an effective national innovative strategy and a pro-innovation policy of development. An element of this policy must be an effective system of support for innovative business activity. The level of such support is very low. Especially in terms of tax support Poland against European countries is assessed negatively (Fig. 3). Poland has ineffec- tive support for the transfer of innovations (the company can deduct from the tax base $50 \%$ of expenditure on the purchase of new technology), and Polish law does not provide a tax support for $\mathrm{R} \& \mathrm{D}$ activities of enterprises.

A modern enterprise is not limited to just one form of innovation activity - the transfer of innovation or generating its own innovative products. Usually, the efficiency of this or another innovative product is assessed in the framework of an appropriate investment project realization and measured as a relationship between the result (profit, revenue, production) and the effort (cost, size of the resources, invested capital etc.). However, these indicators do not reflect the level of the efficiency of innovative activity in the long term. This is due to several reasons. On the one hand, it is not always possible to precisely calculate the results of the innovative product implementation, especially when it is an absolute novelty which has no substitutes. Very often such an innovative product has a multiplier effect, because it can be used in the areas which were not included in the initial introduction of the innovative product in practice. On the other hand, the existing methods for evaluating the effectiveness of investment projects do not include the costs of creating intellectual capital, which largely contributes to the reduction of expenditures on creation and implementation of innovative products.

To calculate the effectiveness of innovative activities of the company, it is necessary to consider longterm characteristics. This effectiveness can be measured by the coefficient of effectiveness of innovative activities, calculated as:

$$
E=\frac{\sum_{i}[I i-(C T i+C H C i+C M i)] * D i}{\sum_{i}(C H i+C H C i+C M i)},(1)
$$

where $I i$ - income from innovative activities in the $i$ th year, $C T_{i^{-}}$cost of total direct innovation activities in $i$-th year, $\mathrm{CHC}_{i \text { - }}$ the cost of creating the human capital in $i$-th year, $C M_{i}$ - the cost of marketing activities related to innovation activities in $i$-th year.

Costs (investments), related to innovation in the calculation of the efficiency level of innovation, very often include only direct investment in a particular project, then their size is influenced by the previously created human capital. The costs of creating the human capital translate into generating and implementing numerous innovative projects. The evaluation of costs of creating the human capital in the context of a single project seems to be quite a difficult task.

\section{Summary}


The main goal of the company in the market is to maximize profit in the long run. However, the estimation of the profits, which the company achieves as a result of an innovative project, usually includes only direct operating profits. Nevertheless, the enterprise achieves internal and external results. Internal results occur in the form ofemployees' increasing experience and skills, which translates into a reduction in the average cost of production and generating new innovations. The final result also contributes to the increase in profits. External market results can be seen in the form of brand creating, growth in demand for production of the company, the possibility of raising prices, an increase in bargaining power in dealing with potential partners, the possibility of negotiating better conditions for cooperation in the fields of $\mathrm{R} \& \mathrm{D}$, production, distribution and promotion.

\section{Literature}

1. No staffing strategy does not help Polish companies WNP.PL $2014 \quad$ http://www.wnp.pl/wiadomosci/217063.html, access on the day 01.10.2015.(In Polish).

1. Clayton C. M., Scott A.D., ERiK R.A. Innovation. Nex step., Harvard Business School Press, Wydawnictwo Studio Emka, Warszawa 2010.

2. DRUCKER P.F., Management XXI, Warsaw, Poland 2000.

3. MARCINIAK S.: Innovativeness and competitiveness of the economy. C.H. Beck, Warszawa 2010. (In Polish).

4. KLUZEK M., Tax solutions supporting innovation.,ZarządzanieiFinanse” 2013/2/2, p. 154.(In Polish).

5. OECD, OSLO MANUAL Guidelines for Collecting and Interpreting Technological Innovation Data, 3rd Edition, OECD/Eurostat, Paris 2005.

6. OKSANYCH O. 2014 Increasing the competitiveness of the company by the development of human capital, chapter 8, In: Toyotarity. Change Management, S. Borkowski, V.M.Ipavec (ed. ) Alba Iulia 2014, p. 92103.

7. PANGSY-KANIA S., E. OKOŃ-HORODYŃSKA, Innovativeness in building a knowledge economy in Poland,InstytutWiedzyiInnowacji, Warszawa 2007. (In Polish).

8. Prahalad C.K., Krishnan M.S. Nowa era innowacji, PWN, Warszawa. 2010(In Polish).

9. Statistical Yearbook of the Republic of Polish 2014 Warsaw 2014. (In Polish).
10. SCHWAB K. (ed) 2014 The Global Competitiveness Report 2014-2015 http://www3.weforum.org/docs/WEF_GlobalCompetitivenessReport_20 14-15.pdf, access on the day 01.10.2015.

11. SteWART L.A., WARDA J., AtKInSON R. 2012We're \#27!: The United States Lags Far Behind in R\&D Tax Incentive Generositysp.11-12. http://www2.itif.org/2012-were-27-b-index-tax.pdf, access on the day 01.10.2015.

12. ZADURA-LICHOTA P.(ed) Innovative entrepreneurship in Poland. Outdoor and hidden potential of Polish innovation. Report PARP http://badania.parp.gov.pl/files/74/75/76/479/22512.pdfaccess on the day 01.10.2015.(In Polish).

13. SZOPIK-DEPCZYŃSKA K., DEPCZYŃSKI R. Innovative activity of small and medium-sized enterprises (SMEs) in terms of the competitiveness of enterprises.STUDIA I PRACE WYDZIAŁU NAUK EKONOMICZNYCH I ZARZĄDZANIA NR 25 UniwersytetSzczeciński, 2012, s. 378.(In Polish). 